\title{
Article \\ How a Collective Trauma Influences Ethno-Religious Relations of Adolescents in Present-Day Sarajevo, Bosnia-Herzegovina
}

\author{
Merima Šehagić \\ Independent Researcher, Germany; E-Mail: sehagicm@gmail.com
}

Submitted: 30 October 2015 | Accepted: 29 March 2016 | Published: 19 April 2016

\begin{abstract}
This article combines a historical perspective on intergenerational transmission of collective trauma with a psychoanthropological approach in regards to the construction of multiple identifications by Bosniak adolescents growing up in Bosnia and Herzegovina, after the Balkan war that took place in the early 1990s. This research is based on the ethnographic fieldwork I conducted during my three-month stay in Sarajevo, a city that has been the center of battles between Bosnian Serbs and Bosniaks. The aim of this research is to understand the ways in which memories of the war linger on in contemporary interethnic and interreligious relations. I applied Dialogical Self Theory to analyze dilemmas and ambiguities emerging from the multiple identifications of Muslim adolescents, to whom coexistence with Bosnian Serbs has come to be part of everyday life. During oral histories, my informants expressed a desire to maintain a sense of normality, consisting of a stable political and economic present and future. I argue that nationalist ideologies on ethno-religious differences which were propagated during the war stand in the way of living up to this desire. On a micro level, people try to manage their desire for normality by promoting a certain degree of social cohesion and including the ethno-religious other to a shared national identity of 'being Bosnian'.
\end{abstract}

\section{Keywords}

Bosnia-Herzegovina; collective trauma; Dialogical Self Theory; ethnicity; group identity; post-conflict coexistence; reconciliation

\section{Issue}

This article is part of the issue "Religious Diversity and Social Inclusion", edited by Gary Bouma (Monash University, Australia).

(C) 2016 by the author; licensee Cogitatio (Lisbon, Portugal). This article is licensed under a Creative Commons Attribution 4.0 International License (CC BY).

\section{Introduction}

The research group of this article consists of Bosniak ${ }^{1}$ adolescents living in Sarajevo, Bosnia. I have consulted the personal narratives of my informants in order to gain a better understanding of their cultural and personal identifications. My informants grew up, partially, in a conflict setting, transitioning from ethnic hostility to a peaceful coexistence with the different ethnic

${ }^{1}$ Bosniak refers to an ethnic group mainly situated in Bosnia, but also in the rest of the Balkans. Though not all Bosniaks are Muslim or practice the religion, within this article the informants do share an ethno-religious Islamic Bosniak background. groups in Bosnia. During the life stories ${ }^{2}$, these Bosniak adolescents spoke about their memories of the Bosnian civil war from 1992 to 1995, during which Bosnian Serbs, Bosnian Croats and Bosniaks fought for Bosnian territory. My key informants emphasized how this ethnic conflict is no longer part of their present, everyday lives. They identify themselves most with being citizens of Bosnia-a tolerant interethnic country. As these findings seem to be ideal for the conservation of the current peaceful situation in Bosnia, I had my questions about how my informants perceive the Bosniak part of

\footnotetext{
2 Questions for the interviews originate from: Atkinson, R. (1998). The life story interview. Qualitative research methods. London: Sage University Paper.
} 
their identity and the rather rapid establishment of reconciliation, which broadly refers to a process through which a society moves from a divided past to a shared future (Bloomfield, 2003, p. 12). A rapid reconciliation seems unlikely, especially because analysts concerned with post-conflict Yugoslavia point out how most people in former Yugoslavia seem significantly less able to rebuild functioning relationships across ethnic boundaries. Existing and rather pessimistic views on the (re)building of feelings of tolerance and trust toward each other by the different post-Yugoslav populations hinder this process (Stefansson, 2010, p. 63). In order to understand these perceptions, it is necessary to consult the different ways in which academic literature has conceptualized the process of reconciliation. Firstly, a distinction between 'thin' and 'thick' reconciliation has been made (Eastmond, 2010, p. 4). The former is based on the actual departure from violence and refers to a more open-ended and fragmented process (Borneman, 2002) while the latter, 'thick' reconciliation, looks more thoroughly at the quality of relationships and coheres with a mutual understanding of unity derived from a common past and shared future. Within this more idealistic stance, key factors for social as well as individual healing are acknowledgement of the ethnic other, and forgiveness (Amstutz, 2005; Lederach, 1997). Others have taken a more pragmatic stance in the debate by arguing that the only realistic scenario, at least in the short term, is a definitive level of social interaction and cooperation between former enemies. Social scientists have shown how specifically in the Bosnian case, reconciliation is understood more pragmatically as peaceful coexistence in the sense of 'respectful relations' and 'life together' (Eastmond, 2010, p. 5). Within this discourse, both research and practice have often focused on a more institutional reconstruction of post-conflict societies. To understand local meanings and social realities of reconciliation, ethnographic fieldwork is crucial in order to provide a substantial and complete understanding of this process of healing for both society and individuals. This article provides a counterview on existing pessimistic attitudes on living together in postconflict Bosnia and is therefore an essential contribution to the academic discourse of post-war settings.

I asked myself how the Bosnian collective trauma ${ }^{3}$ was transferred to a generation who grew up in the

\footnotetext{
${ }^{3}$ With the different definitions of the term 'collective trauma' I refer to "a shared mental representation of a traumatic past event during which the large group suffered loss and/or experienced helplessness, shame and humiliation in a conflict with another large group" (Volkan, 2001, p. 87). In this specific case study the term 'trauma' continuously refers to the collective trauma of the Bosniak ethnic group in Bosnia that experienced brutal sectarian violence and widespread ethnic cleansing between 1992 and 1995.
}

middle of it, approximately twenty years after the outbreak of the war. What caused this cohesive thinking to emerge amongst adolescents who were victims of war themselves? The main research question for this ethnographic study was therefore: How has the collective trauma of the Bosniak ethnic group influenced the identity formation of adolescents, as well as their ethno-religious relations with people from the Serb ethnic group? At first glance, anthropology, focused on the interpretation of socio-cultural relations between people, might not seem to be a matching discipline for researching the conceptualization of identity-a notion traditionally applied to the individual. However, in recent years there has been a shift in the meaning of the core of concept 'culture' within anthropology; the concept no longer merely coheres with the relations between people, but also with the dynamic relationship of the individual and the community (van Meijl, 2009, p. 37). This has caused an increased interest in the concept of identity (van Meijl, 2009, p. 38). The role of social anthropologists in this discourse is to emphasize the diversity and possible frictions within the identification repertoire of the self. Before coming closer to the answer of my main research question, I will firstly elaborate on the methodology consulted during my fieldwork period of three months. Hereafter follows the contextualization of my fieldwork location and the Bosniak community. This is needed, due to the high complexity and sensitivity of the history of Bosnia. I will move on to the presentation of my theoretical framework on group identity, together with my fieldwork findings related to this. Thereafter follows a theoretical presentation on individual identifications, which is necessary to understand interethnic relations on a micro level. Dialogical Self Theory (DST) is an essential framework for understanding individual identifications and the self; the concept will be linked to the personal narratives of my informants. Finally, I will present my conclusions, by revisiting my research question.

\subsection{Methods}

During my fieldwork period of three months, I conversed with different citizens of Bosnia who have shared their stories with me. My landlord, roommates and friends of acquaintances, have provided stories about their life course, humorous and striking anecdotes about the war, and so on. My dual background of Dutch and Bosnian helped me to investigate the narratives in a broader cultural context. Being a 'native anthropologist', I was not studying a distant culture, moreover, I was already familiar with, for example, the language and certain cultural values, being that these match my own cultural background, to an extent (Narayan, 1993, p. 671). The social network I developed during my stay made it easier for me to come in contact with my five key informants: Bosniak adolescents 
who were between 21 and 24 years old at the time of my fieldwork, living and studying in Sarajevo and who had lived in Bosnia during and after the Bosnian war in the 1990s. Two of my informants described themselves as "not really religious", while the other three were consciously practicing Islam either through prayer or, for example, by fasting during Ramadan. I embraced this diverse religiosity within my research group, as I believe it corresponds with the Bosniak community in Bosnia, where the practice of Islam is a strong mixture between secularized Muslims and those who strictly live by the rules of Islam. My key informants have in common that they were all strongly affected by the outbreak of the war. Two have lost their father during the conflict; others were confronted with severe forms of violence or discrimination. These youngsters were interested in helping me with my research, for the mere reason that they were able to do so. Some had doubts if they could provide me with 'the right' information for my research. As one of my informants told me, "I'd love to meet up. I'm a student and a Bosnian Muslim. Not a religious person, though. But it seems that you're just looking for Bosniaks? Let me know if I'm wrong." This informant is somehow immediately distancing himself from the religious dimension of his ethnic background. While this seems to be contradicting, in the section The Breakdown of Yugoslavia I will explain in further detail how it is not so strange to consider oneself as part of an ethno-religious group, without being a religious person.

I initially met with all my informants in a similar way, during a short chat over coffee somewhere, in a café or in a park. This first meeting was meant as an introduction, not only to each other, as individuals, but also to grasp if we could form a longer working relationship with one another and complete a more intense life story interview. During this first meeting, one of my informants told me about his family's stay in Germany for several years during the war. As he grew up outside of Bosnia for a period of time, I could not include this person to my sample. He did however lead me to my first key informant, because they were living together in a flat share. This qualitative method of 'snowball sampling' (Babbie, 2007) is relevant for postconflict research due to the sensitivity of the topic and has helped me to find my informants. After the first meeting with my key informants, it varied per person how much time we were able to spend together before and after conducting the recorded interview. In the context of cooking together, taking a walk or having a drink, I was able to practice participant observation (Spradley, 1980) to gain a better understanding of the social and cultural contexts my informants are placed in. In practice, this entails that we were part of the same community for a short period of time and that I was introduced into their personal and social lives. I had the opportunity to talk about 'off-topics' such as music preference, artistic interests and the more personal developments of my informants. This 'deep hanging out' is a very basic qualitative research method which enables close contact with informants and their everyday worlds of meaning and provides a perspective 'from below' (Geertz, 1998). Finally, during the recorded life stories, I started with the circumstances and the environment my informants were born into. For example, what they could remember about their first years as a child and how they would describe their parents. I also asked questions related to important social others from their neighborhood they looked up to, tensions they experienced in school and how they filled in their free time. Though these specific stories are not presented in my analysis, they help with understanding personal experiences and balancing these experiences with more general historical developments (Leydesdorff, 1996; Tonkin, 1992).

\section{The Breakdown of Yugoslavia}

\subsection{Tito's Communist Regime}

The different peoples of former Yugoslavia share a long history and the multi-ethnic structure of the area is central to the events that took place during the war. Even though Bosnia has just become an independent country at the end of the last century, the Bosniak ethnic group had emerged far before the breakdown of Yugoslavia. Between 1953 and 1980 Josip Broz Tito was president of Yugoslavia and by many citizens of Bosnia, this period is described as a harmonious time where conflicting ethnic groups were 'finally' able to live together in peace. This so-called peace did indeed come, but it was more related to imposed communist power-enforced by mass shootings between 1945-46, death marches and concentration camps-than to reconciliation policies. Tito's secret police sowed fear through punishment and intimidation amongst those in Yugoslavia who did not agree with his regime (Malcolm, 2002, p. 193). Even though the 1946 constitution of Yugoslavia acknowledged the freedom of belief, multiple sanctions carried out under communist rule provided argument for the opposite. In 1950 a law was issued with regard to the Bosniak group that concerned the prohibition of wearing a veil, the closing of elementary schools where children learned the basics of the Koran and it was even against the law to teach children in mosques (Malcolm, 2002, p. 195). These measures taken against Islamic religious life in Yugoslavia lasted for several years, but in the late 1950s and 1960s a noteworthy change occurred concerning the Bosniak community. Tito changed the general treatment of Islam and he started to use the community to promote his new foreign policy, advocating a more Western approach. The main reason for this change can be traced back to Stalin ejecting Yugoslavia from Cominform-a 
Soviet dominated organization aimed to coordinate actions between Communist parties. This made Tito and his country very dependent on the West, for loans and moreover, for diplomatic support. In other words, he needed a Bosniak community in order to succeed in keeping the Western democracies on his side (Malcolm, 2002, p. 196).

\subsection{The Bosniak Fight for Recognition}

In the early 1940s, the Bosniak community in Yugoslavia was mostly considered a problem by the Yugoslav Communist Party. This problem was thought to solve itself, due to the community gradually fading away, as its members would eventually identify themselves with the Croats or Serbs (Malcolm, 2002, p. 197). The issue was however far more complicated than this. Even though its neighboring republics treated Bosnia as a piece of territory ready to be divided amongst them, the Bosniak community was seeking for recognition, specifically in the sense of national territory. One reason for this was the policy drop of 'integral Yugoslavism', which caused for the separate republics to strengthen their national identities. Another reason for this desire towards recognition was the structure of the Communist Party within Bosnia, where Muslim communist officials formed a small elite (Malcolm, 2002 , p. 198). One could thus conclude that the rise of the Bosniak community was not a movement originating from merely Islamic religious grounds. The drive towards recognition of the community as a national category was in matter of fact, a political move, led by communists and other secularized Muslims, who would benefit from the development of a Bosniak identity (Malcolm, 2002, p. 200).

I will now explain why and how exactly the development above would be beneficial. Bosnia was considered lower in status than the other republics of Yugoslavia, which was thought to come from the belief that the republic was not a distinctive nation, but that Bosnia only consisted of fragments of the Serbian and Croatian nations (Malcolm, 2002, p. 201). The census in 1948 on the nationality of the citizens of the Bosnian republic also gives a clear picture of the way the region had been portrayed. Bosniaks had the option to classify themselves as 'Muslim Croat', 'Muslim Serb' or as 'Muslim: nationality undefined'. At least 778.000 people chose the 'undefined' classification, whereas only 72.000 chose 'Muslim Serb' and 25,000 chose 'Muslim Croat'. These statistics show the marginal willingness of the Bosniaks to identify themselves with the neighboring republics (Malcolm, 2002, p. 198). This perception of Bosniaks stems from the late nineteenth century when Catholic and Orthodox Bosnians started to identify themselves as Croats and Serbs, purely based on their religion. These ethnic labels caused for further complexity regarding the ethnic genealogy of Yugosla- via, consisting of peoples sharing the same language and history. Moreover, this made it impossible for 'Bosnian' to be a third ethnic category, as the existence of Bosnian Serbs and Bosnian Croats had arisen. Therefore, the Muslims needed a specific Bosniak identity as a national identity, as they believed this development would prohibit Bosnia from getting divided amongst the two other republics (Malcolm, 2002, p. 200). Anthony Oberschall (2000) concludes that before the fall of Yugoslavia, it was not a necessity to know to which ethnic group your friends or neighbours belonged to. It was only after the increased influence of the mass media and the populist movement after Tito's death in 1980 that people started to look differently at their fellow citizens. Those with whom they worked and lived had now become what they considered the enemy (Oberschall, 2000, p. 988). This more idealized view does not take into consideration the changing characteristic of attitudes towards other ethnic groups related to, for instance, different periods in history. Tone Bringa (1995) emphasizes that before the war, Bosnia was not simply an unquestionably tolerant and cohesive society where citizens felt no need to classify one another under the ethnic labels of Serb, Croat or Bosniak. Nor does she believe the opposite 'age-old hatreds' approach to be accurate, which implies that the ethnic groups in Bosnia have always hated each other and that the seemingly tolerant society under Tito's regime was merely the result of communist suppression. What can be concluded from this is that there were both tolerance and prejudice in Bosnia and that to some, an ethnic label was of importance, but to others, it did not matter. These attitudes are strongly dependant on a person's age and the socio-cultural environment they grew up in (Bringa, 1995, p. 3).

\section{The Collective Identity}

\subsection{Chosen Trauma}

The Bosnian war in the 1990s was a period in which, characteristically, it became more customary for wars to occur within states instead of between them. We are dealing with groups who had many similarities, considering their shared histories, yet they were stressing their significant differences (Volkan, 2001, p.79). As I have explained in the historical background section, the development of the Bosniak identity, as a collective identity, was strongly dependent on the other ethnoreligious identities within the country. The Serb group identity, specifically, has had a lot of influence when looking at the violent events that took place between the two. One can define group identity as a subjective experience of thousands or millions of people who are connected by significant similarities, yet at the same time there are shared characteristics with members from other ethnic, national or religious groups. The 
most important task of the members of a large group is to preserve, to protect or to recover the collective identity of the group (Volkan, 2001, p. 81). I will focus mainly on one specific aspect of group identity, which is most relevant to my research. This is the way in which a violent and traumatic event from the past becomes part of the group identity in the present and therefore also for later generations of the same group. With this I am referring to the process where sharing trauma can become an essential part of the bonding between different individuals from a group. A traumatic experience or event can later, especially with the future generation, be used to protect the then threatened group identity. This transgenerational transmission of trauma can be connected to the incapability of the previous generation to process the trauma and often the interconnected humiliation of the ethnic group. The task of the next generation, as it is the case with my informants, would be to eventually process the losses and humiliations (Volkan, 2001, p. 87).

Due to the strategic aspect of the use of the trauma, the term 'chosen' trauma is most suitable according to Vamik Volkan (2001). He emphasizes that the group may not have chosen to become victims of violence, yet they have chosen to connect this trauma to their present-day group identity. The most important thing about chosen trauma is that it is not merely a shared memory. The circumstances during the time of the historical event do not need to be relevant or true in the present, but it still retains a certain function. Furthermore, the trauma does not need to be present in the everyday lives of individuals, as its power lies unconsciously, playing a role in the identity of the members of a group and in that it can always be reactivated (Volkan, 2001, p. 88). This reactivation generally occurs, under more stressful circumstances. The fears that are interconnected with the trauma come to the surface and the members of the ethnic group experience the trauma as if it was once again a danger (Volkan, 2001, p. 89). In The manipulation of ethnicity: From ethnic cooperation to violence and war in Yugoslavia, Anthony Oberschall (2000) acknowledges a similar moment of reactivation, when he makes the distinction between a 'normal' frame and a 'crisis' frame. The normal frame is linked to more usual circumstances, under which memories are being suppressed and one does not consciously think about the past. I think the crisis frame of Oberschall joins the moment of reactivation of Volkan, as the suppressed memories from the past have the opportunity to come up due to, among others, feelings of fear. Furthermore, Oberschall explains the increased fear from a political perspective, as he believes the role of (populist) political elites and their use of mass media is crucial to the reinforcement of fears from the past (Oberschall, 2000, p. 989). I will focus on the situation during my fieldwork, where ethnic groups live together in peace within a normal frame. What I was able to research, is the role that these historical events during the Bosnian war have had thus far on the lives of Bosniak adolescents. For this reason, I asked my informants about their perceptions and their memories of the conflict.

\subsubsection{Remembering 1992-1995}

It is true that not all of the citizens of Bosnia have been severely influenced by the violent events during the war, for instance, through fleeing the country or settling in a safe area. My informants are however far from an example of this. Two out of the five key informants I have spoken to on a regular basis have lost their fathers during the conflict. Most of my informants were also situated in Sarajevo at the time the city was under siege. Even though they have few memories of the war, the stories my informants told can be described as vivid and detailed. One of my key informants is Harun, who grew up in Sarajevo. At the time our interviews took place, he lived in Sarajevo with his mother and was studying Political Science. He had told me about his childhood, how his father grew up in a communist Yugoslavia and how this has had an influence on his perceptions of ethnicity up to this day. The fragment below is part of his answer when I asked him what personal memories he had from the war:

"I was told that I had not seen the sunlight until I was, I think, three years old. This was not possible at all, you could not risk the danger of going on the streets, because you might get shot by a sniper. Or, I don't know, be killed by a grenade. I have a picture; it is not a real photograph, but a combination of five or six snapshots of a falling grenade. See, the grenade fell in the area around my building and it blew up my neighbor's leg. Yes, this is what I can remember. I can perfectly remember the sound of the grenade and I still have this image of blood, everywhere, and him screaming. It was in the middle of the day I believe, around three o'clock." (Interview Harun, July 2012)

Equally, or even more intense, were those descriptions my informants had no personal memory of but that had been passed on to them by family members and their friends. Another key informant was Haris, who did not grow up in Sarajevo, but was living and studying there at the time of my fieldwork. He lost his grandfather during the war and explained to me how his own father had become a different, almost unrecognizable person after the conflict. He told me what he remembered from the stories he had heard from others:

"I remember stories about how they murdered pregnant women, how they burned children in ovens. I remember, I don't know if it is true or not, but 
I remember that a man told me about two Serbs who attacked a pregnant woman. They had placed a bet for a crate of beer, betting whether the woman was pregnant with a boy or a girl. And they just cut open her stomach." (Interview Haris, July 2012)

Haris also told me stories about the aftermath of the Bosnian war. This time, he spoke about his own experience with Serbs when growing up. During his teenage years, an introduction meeting was organized at his high school where everyone was supposed to tell a little bit about themselves. After one of his classmates said they came from Srebrenica, a city known for the killings of Bosniak men and boys, a group of Serb boys started laughing and commented: "we thought that we had gotten rid of all of you there". This can be described as a very unpleasant experience, at the least. One might even think that this small encounter could be classified as traumatizing, whilst the threats from 1992-1995 are being brought to a peaceful, 'normal frame', although disguised in humor. The last memory I wish to present here, is from Amra, a key informant who was studying veterinary medicine in Sarajevo. She had to move a lot when she was a child, also due to the insecurity of certain areas during the war. She comes from a very religious family and has the most memories of the war, as she was my oldest informant. She told me the following story from her teenage years:

"I experienced such a culture shock when I moved to an area where the different ethnic groups were living together and where they could not stand each other. You are not able to go out somewhere, because the owner happens to be a Serb. You are afraid to go to a place, because you know you are not welcome there, because my name is Amra." (Interview Amra, August 2012)

Amra is talking about an experience, which she describes as shocking, because for her this kind of hostility between ethnic groups was not normal. I will come back to the impact of these experiences in the next section, where memories will be placed in the present everyday lives of my informants.

\subsection{Chosen Amnesia}

Haris' story about the pregnant woman became part of his memory about the war even though he was not sure whether or not the story had actually happened. Memories from the past can take up a shape which does not necessarily coincide with truths. The story told to Haris, true or false, can be employed for diverse goals. Richard Esbenshade (1995) emphasizes that it is not so much about looking at the factual truths of a history; moreover, it is of greater interest to look into the different contextual ways in which the past is being re- membered by groups. In this way, Esbenshade breaks with the dichotomy of remembering versus forgetting, because they both belong to memory, and therefore, to history (Esbenshade, 1995, p. 87). Remembering can go as far as ultimately becoming dangerous for a people or culture, therefore Esbenshade poses the question if there is such a thing as strategic forgetting in order to enable individuals and nations to live on. This is precisely what Susanne Buckley-Zistel (2006) focuses on in her theory on how groups deal with traumatic events in a post-conflict environment. With her fieldwork in postgenocide Rwanda, she describes how Hutu's and Tutsi's experience their past as peaceful, whereby the genocide is seen as a sudden break in cohesive society. In order to fully understand life in a post-conflict environment, Buckley-Zistel finds it necessary to look at the way in which group identity is constructed in a memory discourse (Buckley-Zistel, 2006, p. 132). She argues that the memory is still present in the minds of individuals, even though it seems as if they do not have any access to this in the present. Buckley-Zistel's explanation for this is that both groups are dependent on each other in their daily lives and that the presence of any form of cohesion is essential for a 'normal' life with the former enemy. The way to reach this social cohesion is through a chosen amnesia. There is no sign of denial of the past, therefore the term 'chosen' is applicable. The memories are still present, but according to Buckley-Zistel, the members of both groups have consciously chosen to exclude the events from the memory discourse of the group, in order to live peacefully with the other (Buckley-Zistel, 2006, p. 134). Buckley-Zistel (2006) illustrates the reversed process from that of the chosen trauma explained by Volkan (2001), where historical events are included in the group identity in order to form a sense of belonging. Furthermore, the theory of chosen amnesia goes hand in hand with the acknowledgement of a collective innocence. According to Buckley-Zistel, both groups are excluded from fault because the elite which was in power during the conflict is held responsible for creating distinction and violence between the groups. My informants have described this phenomenon in their stories:

"It is all the manipulation of a few people, the ignorance of people. You only have knowledge of what is being told on the television and on the radio. They (the Serbs) cannot classify as those who have murdered, who have raped. You cannot blame the people, they did not want this to happen, no one wanted for this to happen." (Interview Haris, July 2012)

"It was a great country around the time of my birth. I believe it was a mixture of Western culture and our own Balkan way of life. Sadly, this had been ripped into pieces because of the wrong ideas of a 
few political leaders." (Interview Harun, July 2012)

This collective makes it possible to live together with the other group, as they are not considered guilty and were also manipulated from above (Buckley-Zistel, 2006, p. 140). I think that this aspect of the concept of chosen amnesia is strongly applicable to the Bosnian case. However, in the previous section, Remembering 1992-95, the narratives of my informants demonstrate that they do remember the crimes committed by individuals from the other ethnic group. In this sense, it seems inaccurate to claim that they do not have access to the memories of the war, as the conceptualization of chosen amnesia implies. Rather, these memories of the violent ethnic conflict seem to be strategically repressed. The activity of repression is what Freud considers to belong to the 'unconscious' and which is needed in order for social life to be routinely enacted (Billig, 2006, p. 22). Applying this train of thought to the stories of my informants, memories from the war that are disturbing the 'normal life' both ethnic groups share in the post-conflict society need to be regularly and actively repressed. As the necessity for repression originates from social activity (Billig, 2006.), this is another strategy-besides collective innocence-which helps my informants to reconcile and reach not only social cohesion, but also social inclusion. I shall therefore apply the selective chosen amnesia and the repressed nature of forgetting to the further analysis of my findings in Sarajevo.

\subsubsection{The Aftermath of War}

I have asked my informants the extent to which they agree with statements related to living together with the Serb ethnic group in Bosnia ${ }^{4}$. Examples of some of the statements are: Serbs and non-Serbs have different family values, I want Serbs to adopt Bosniak culture and not to keep their own, I want Serbs to be friends with both Serbs and non-Serbs. This very small sample showed me the perceptions of my informants regarding the integration, assimilation and segregation of the Serb ethnic group in Bosnia. They all seemed to be against the segregation of this group and very adamant for the integration of Serbs, without the Serb group having to sacrifice their cultural values for Bosniak values. My informants placed a high value on living together with the diverse ethnic groups of Bosnia, not just the Serbs. With this it is meant that social contact, social activities and social attitudes are not to be based on the ethnic background of social actors. Still, there are sometimes situations for my informants where the events from the war influence the ethnic relations in a negative way. The below quote from Haris illustrates perfectly how even though he has a tolerant mind-set,

${ }^{4}$ The questions were derived from Ljujic and Dekker (2012 he can still feel some kind of ethnic tensions:

\begin{abstract}
"Yes, there exists some kind of, how can I put it...a restraint, a fear. Every time I find myself alone, which means alone with only Serbs around me, this gives me a very strange feeling. How they, Serbs, are looking at me, as a Muslim." (Interview Haris, July 2012)
\end{abstract}

Even though the very recent Bosnian war had a strong impact on the lives of my informants, this does not imply that it was this conflict and its ideology that remained the most significant factor to their identity formation. More important are the different ways in which the past is being translated into the present, with the help of memories and storytelling. A clear point in the narratives of Bosniak adolescents was how they valued their upbringing. What their mothers, fathers or grandparents told them about the war was far more significant to them than the factual casualties and cruelties during the conflict. The following quotes from my interviews illustrate exactly what kind of values my informants were taught when growing up:

\begin{abstract}
"My whole life I have been listening to what was going on during the war. At all of the family meetings and always when I was with my father. It starts off normal, but then after a few minutes the subject shifts to the war. Who betrayed who? Who attacked who? It's always about the war. How was it possible for an ethnic group, not different from the Bosniaks, to attack Sarajevo? Okay, we can count religion as a point of difference, but the culture is almost identical...I have friends who are Catholic, I have friends who are Orthodox, I even knew a few Jewish people. This helped me to accept all of the religions, to see them as one." (Interview Harun, July 2012)
\end{abstract}

"I have to respect people, first of all. It should not matter which religion someone has. I am tolerant and I am not a nationalist. During the war, tragic events have occurred and I have lost a lot of people from my family. Yet I do not have an aversion against others. Everyone is first of all human, after this comes the rest." (Interview Naida, August 2012)

The socio-cultural environment of my informants has led them to choose to never follow the footsteps of those parties involved with spreading hatred in the early 1990s. The war is seen as something from the past and a repetition of this should by all means be prevented. The collective trauma of the Bosniaks has not necessarily caused an increased in-group bonding among my informants, as is the case with the chosen trauma theory of Volkan (2001). Rather, the emphasis on bonding with the Serb ethnic group is being stimulated because of this collective trauma. The priority lies 
on a peaceful coexistence, where both groups live together as fellow citizens of Bosnia. It even goes a step further, as not merely living together but also including the other in social spaces is found to be of great value. Both groups are dependent on each other in their daily lives and some form of social cohesion is necessary to be able to live a 'normal' post-conflict life. There is no case of denial about what went on during the war, but the war is a subject, which my informants are actively repressing in the present.

\section{Dialogical Self Theory}

\subsection{The Position Repertoire of the Self}

The ethnic background of my informants was of such importance during the Bosnian war, that their lives, or their relatives' lives depended on it. Therefore it is interesting to look into the role of ethnicity for adolescents who have lived through an ethnic conflict and who are now living in a peaceful multi-ethnic society. In this section I want to explain how it can be possible for my informants to identify themselves as Bosniak and experience feelings of fear and anxiety towards the Serb ethnic group whilst at the same time advocating the social inclusion of this group and trying to rid ethnic labels. I will do so by introducing Dialogical Self Theory (DST) and connecting it to the narratives of Bosniak adolescents. The core of DST consists of the implication that there is a variety of different I-positions within the self of every human being and moreover, that these positions are in dialogue with one another (Hermans, 2002a, p. 147). One can understand the diversity of Ipositions from the fact that humans do not merely identify themselves with cohesive characteristics. This implies the existence of contradicting identifications within the spectrum of I-positions.

According to DST, during certain moments in a person's life, specific I-positions have the dominant voice within the self. This implies the existence of power relations between the positions, whereby every position is expressing one perspective (Hermans, 2002b, p. 25). Due to this, it becomes possible to place someone's actions within some kind of dominant sketch of character. For example, think of a person who has dominant positions such as being independent, introvert and passive, despite the simultaneous presence of a dependent, extravert and active I-position. Note that it is always possible for a dominant position to weaken, which creates the opportunity for another position from the repertoire to become dominant. This phenomenon is what Hermans (2002b, p. 5) describes as dominance reversal. Now that I have briefly set out the core of the dialogical self from a more psychological perspective, I wish to elaborate on the influences of culture(s) on the position repertoire of the self. The dialogical self is not merely interrelated to the individual, but is also a 'culture- inclusive' concept. Every individual is placed within a specific cultural context and it is this culture that is situated within the self, whilst at the same time transcending this individual self (Hermans, 2002b, p. 25). For a great deal, cultures strongly influence the content as well as the organization of the self, by manifesting in it in the form of collective positions, which are the result of historical processes. Cultures are therefore not 'things', but in fact, processes that color the individual self. This does not imply that only the culture to which a person belongs is part of their position repertoire; other potentially conflicting cultures are part of the self as well (Hermans, 2002b, p. 26).

As I have described in my introduction, we are living in an increasingly globalizing world where different cultural processes are crossing and as a result these junctions are becoming more interesting for current and future research within the social sciences (Hermans, $2002 b, p .26)$. Due to the culture inclusive aspect of the self, globalization has a noteworthy influence on the complexity of the self (Hermans, 2002a, p. 148). This makes it scientifically necessary to look into the development of (changing) dominant collective positions in contexts where diverse cultures cross each other. As my informants are in this exact position, I shall continue with the further elaboration of the multicultural position repertoire of my informants' selves in order to fully understand their shared dilemmas and ambiguities.

\subsection{Multiple Multicultural Identifications}

One of the important cultural identifications within the position repertoire of my informants which I have come across is that of being a member of the Bosniak community and identifying oneself with an Islamic ethnic group. The other relevant I-position is that of being a citizen of Bosnia, which at first does not necessarily have to be in contradiction with the other position. When one however takes into consideration the complex history of the country and especially of the Bosniak group, the possible friction between the two identifications becomes clearer. On one hand my informants identify with a position which is based on the differences between ethnic groups and on the other, there is an identification which emphasizes a unity with the other ethnic group and which strives to transcend ethnic labels. The following quote from Harun illustrates his Bosniak identification whilst together stressing a 'sameness':

\footnotetext{
"Even though I might have an Islamic name, I pretty much have the same habits as a Serb, including all of the things that are forbidden within Islam. For instance, drinking (alcohol) and eating pork meat. Besides, our closest family friend is also a Serb." (Interview Harun, July 2012)
} 
Rather early in my fieldwork, it became clear to me that my informants view their Bosniak identification as part of who they are, whilst rejecting it on certain levels. They believe that people who put too big of an emphasis on differentiation based on ethnicity are somehow linked to the ideology behind the Bosnian war. As my informants reject this nationalist ideology and perceive it to be part of the past, identifying oneself too much with being specifically Bosniak can contradict the values they strongly believe in. The following part from Selma's narrative shows how the desire to de-emphasize ethnic labels is directly linked to the ethnic conflict in the early 1990s:

"Tolerance towards everyone, that is what I have learnt from my family. I do not categorize people, especially after the war when the divisions were really large. I do not categorize people based on their religion or nation, merely on being good or bad people...I do not wish for a multicultural society, but for an intercultural society. This implies to not only tolerate the other, but also to acknowledge the other and actually interact with them, in a positive way of course." (Interview Selma, July 2012)

I conclude that the Bosniak fight for recognition and its belonging, Bosniak identification has had to make room for a more national, cultural position, which I think is an example of the earlier mentioned notion of dominance reversal. This identification can also be explained by the Common Ingroup Identity Model (CIIM) which argues that members' group boundaries perceptions of ' $w e^{\text {' }}$ and 'them' can be transformed to a more inclusive 'us' (Gaertner, Dovidio, Anastasio, Bachman, \& Rust, 1993). The dominance reversal which I have elaborated on, indicates a new perception on intergroup boundaries and according to the CIIM, this enables intergroup conflict to shift towards establishing more harmonious intergroup relations (Gaertner et al., 1993, p. 2). This recategorization, together with the reduction of bias, can ultimately contribute to a common ingroup identity (Gaertner et al., 1993, p. 3). By no means does this imply the dissapearance of the two ethnic groups, but rather, a new group structure is created which includes former 'outgroup' members and leads to positive attitudes (Gaertner et al., 1993, p. 6). The stories of my informants have shown how this can result in a distinct feeling of sameness, even pointing out that there is not that much difference between Bosniaks and Serbs.

\section{Conclusions}

In the introduction I raised the question: How has the collective trauma of the Bosniak ethnic group influenced the identity formation of adolescents as well as their ethno-religious relations with people from the Serb ethnic group? Both groups are dependent of one another in their daily lives and the presence of any form of cohesion is essential for a 'normal' life with the former enemy. This has caused the development of strategic repression and strategic chosen amnesia (Buckley-Zistel, 2006) in order to enable individuals and nations to live on together. Anthropologist Anders $\mathrm{H}$. Stefansson (2010) describes how peaceful coexistence in post-conflict Bosnia has been made possible. The most important aspect that he raises is the way people deal with the past in everyday life. By silencing sensitive themes related to the war, particularly moral and political issues, a shared everyday life with the ethnic other is made possible. This matches the concept of repression, as well as my ethnographic findings. He concludes that there is a willingness to share a social space with the enemy from the past, which my informants confirm (Stefansson, 2010, p. 62). Marita Eastmond (2010) has also researched everyday life in post-conflict Bosnia. She highlights a different aspect of the coexistence. It is indeed much easier to live together with neighbors and colleagues who are not your enemy. People do have the need for a 'normal life' after such insecure times of conflict. The first and foremost needs are related to material and social security (Eastmond, 2010, p. 11). The reconciliation with the other ethnic group, the former enemy, is not the top priority according to Eastmond. As Bosniaks are busy with rebuilding their lives, she thinks that there is no room for qualitative relations with Serbs. Eastmond concludes that there is a large difference between living together in peace and having actually forgiven what has happened during the war (Eastmond, 2010, p. 12).

This is an interesting point of discussion, as I think it is rather difficult to conclude that the coexistence between Bosniaks and Serbs is merely an everyday necessity. As my informants have illustrated with their narratives, this 'living together' is integrated into their personal and cultural value system. This cannot only be described as a social cohesive society, rather, my informants are socially including this other ethnic group to a shared identification of both being citizens of Bosnia, and also propagating the idea of a collective innocence. I think the narratives of my informants thus indicate a certain degree of forgiveness and therefore, a more 'thick' understanding of reconciliation as well, which is interesting because as in the Bosnian case, specifically, analysts have taken a more pragmatic stance on the debate of reconciliation (Eastmond, 2010 , p. 5). Related to the raised point of discussion, I would once again like to stress the importance of a person's age and the socio-cultural environment they grew up in on their attitudes towards the ethnic other. I think my findings are restricted to the life stories of young, educated people growing up in the multi-ethnic capital of Bosnia, and coming into contact with different ethnic groups on a daily basis. This implicates the boundaries of my research and makes these findings less applica- 
ble to, for example, elderly Bosniaks living in a smaller village which is inhabited mainly by other Bosniaks.

In addition to repressed memories and chosen amnesia, I think that another explanation for this forgiveness can be found within my research group in the way my informants put the emphasis on themselves as 'human' instead of categorizing on the basis of ethnic boundaries. I am referring to the quotes of my informants which I presented under the section The Aftermath of War. Naida for instance stated, "Everyone is first of all human, after this comes the rest." The findings of the empirical study of Wohl and Branscombe (2005) on intergroup forgiveness show how members of the victim group (Jewish participants) were willing to forgive the perpetrator group and assign them less guilt when the victim group was induced to think of themselves as 'human' as opposed to the less inclusive category of 'Jew' (Cehajic, Brown, \& Castano, 2008, p. 353). Furthermore, this study found that higher levels of forgiveness were also related to reduced social distance, which made it more realistic for my informants because they live in Sarajevo, where you find a mixture of several ethnic groups and religions.

\section{Acknowledgements}

This article is the result of a two-year research programme from the Radboud Honours Academy, which offers students from the Radboud University Nijmegen the chance to participate in an additional, challenging programme. The author would like to thank the Radboud University for their investment in this specific research project and especially Prof. dr. Toon van Meijl, for his time and guidance throughout the project. The author would also like to take this opportunity to thank all of the people who have shared their stories in the field. In particular the five key informants; Haris, Selma, Harun, Naida and Amra.

\section{Conflict of Interests}

The author declares no conflict of interests.

\section{References}

Armstutz, M. R. (2005). The healing of nations: The promise and limits of political forgiveness. Lanham, MD: Rowman and Littlefield.

Atkinson, R. (1998). The life story interview. Qualitative research methods. London: Sage University Paper.

Babbie, E. (2007). The practice of social research. Cengage Learning.

Billig, M. (2006). A psychoanalytic discursive psychology: From consciousness to unconsciousness. Discourse Studies, 8(1), 17-24.

Bloomfield, D. (2003). Reconciliation: An introduction. In D. Bloomfield, T. Barnes, \& L. Huyse (Eds.) Reconcilia- tion after violent conflict: $A$ handbook (pp. 10-18). Stockholm: International Institute for Democracy and Electoral Assistance.

Borneman, J. (2002). Reconciliation after ethnic cleansing: Listening, retribution, affiliation. Public Culture, 14(2), 281-204.

Bringa, T. (1995). Being Muslim the Bosnian way: Identity and community in a Central Bosnian village. Princeton: Princeton University Press.

Buckley-Zistel, S. (2006). Remembering to forget: Chosen amnesia as a strategy for local coexistence in postgenocide Rwanda. Africa, 76(2), 131-150.

Cehajic, S., Brown, R., \& Castano, E. (2008). Forgive and forget? Antecedents and consequences of intergroup forgiveness in Bosnia and Herzegovina. Political Psychology, 29(3), 351-367.

Eastmond, M. (2010). Introduction: Reconciliation, reconstruction, and everyday life in war-torn societies. Focaal, 2010 (57), 3-16.

Esbenshade, R. S. (1995). Remembering to forget: Memory, history, national identity in post-war EastCentral Europe. Representations, (49), 72-96.

Gaertner, S. L., Dovidio, J. F., Anastasio, P. A., Bachman, B. A., \& Rust, M. C. (1993). The common ingroup identity model: Recategorization and the reduction of intergroup bias. European review of social psychology, 4(1), 1-26.

Geertz, C. (1998). Deep hanging out. New York Review of Books. Retrieved from: http://www.nybooks.com

Hermans, H. J. M. (2002a). The dialogical self as a society of mind: Introduction. Theory \& Psychology, 12(2), 147-160.

Hermans, H. J. M. (2002b). Het verschil tussen de persoon en zichzelf: De 'dialogical self' als minisamenleving (Valedictory Lecture 29 November).

Kolind, T. (2008). Post-war identification: Everyday Muslim counterdiscourse in Bosnia Herzegovina. Aarhus: Aarhus University Press.

Leydesdorff, S., Passerini, L., \& Thompson, P. (Eds.) (1996). Gender and memory. In International Yearbook of Oral History and Life Stories (Vol. IV). London: Oxford University Press.

Lederach, J. P. (1997). Building Peace. Sustainable Reconciliation in Divided Societies. Washington, DC: United States Institute of Peace Press.

Ljujic, V., Vedder, P., Dekker, H., \& van Geel, M. (2012). Serbian adolescents' Romaphobia and their acculturation orientations towards the Roma minority. International Journal of Intercultural Relations, 2012 (36), 53-61.

Malcolm, N. (2002). Bosnia: A short history. London: Pan Books.

Narayan, K. (1993). How native is a "native" anthropologist? American Anthropologist, 95(3), 671-683.

Oberschall, A. (2000). The manipulation of ethnicity: From ethnic cooperation to violence and war in Yugoslavia. Ethnic and Racial Studies, 23(6), 982-1001. 
Spradley, J. P. (1980). Participant observation. New York: Holt, Rinehart and Winston.

Stefansson, A. H. (2010). Coffee after cleansing? Coexistence, co-operation, and communication in postconflict Bosnia and Herzegovina. Focaal, 2010 (57), 62-76.

Tonkin, E. (1992). Narrating our pasts: The social construction of oral history. Cambridge: Cambridge Uni- versity Press.

van Meijl, T. (2009). Anthropological perspectives on identity: From sameness to difference. In M. Wetherell \& C. T. Mohanty (Eds.), The SAGE handbook of identities, 2009 (63-82). London: Sage.

Volkan, V. D. (2001). Transgenerational transmissions and chosen traumas: An aspect of large-group identity. Group Analysis, 34(1), 79-97.

\section{About the Author}



\section{Merima Šehagić}

Merima Šehagić obtained her Master of Science degree at the University of Amsterdam. Her main emphasis is on migration and post-conflict studies examined from a gendered perspective. Her research focusses on the aftermath of the Bosnian conflict and the identity formation of Bosniak adolescents living in Sarajevo, as well as the reconstruction of self, regarding Bosniak women who were victims of wartime ethnic rape. 